\title{
International Primary Care Respiratory Group (IPCRG) Guidelines: Diagnosis of respiratory diseases in primary care
}

\author{
Mark L. Levy ${ }^{a, *}$, Monica Fletcher ${ }^{b}$, David B. Price ${ }^{c}$, Thomas Hausen ${ }^{d}$, \\ Ron J. Halbert e,f , Barbara P. Yawn ${ }^{\mathrm{g}}$
}

a Division of Community Health Sciences: GP Section, University of Edinburgh, 20 West Richmond Street, Edinburgh EH8 9DX, UK

${ }^{\mathrm{b}}$ Education for Health (incorporating National Respiratory Training Centre and Heartsave), The Athenaeum, 10 Church Street, Warwick, CV34 4AB, UK

${ }^{c}$ Dept of General Practice and Primary Care, University of Aberdeen, Foresterhill Hola (t) Clepre, Westburn Road, Aberdeen AB25 2AY, UK

d General Practice Surgery, Grafenstr. 52, 45239 Essen, G̈emeny

e Cerner Health Insights, Beverly Hills CA LUSA

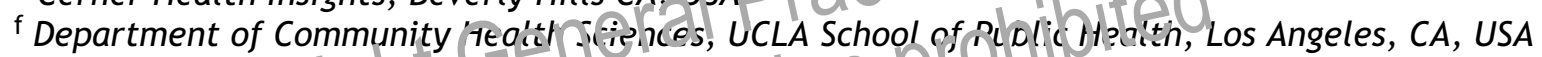

s Department of Fomit. and Enmunity Health, U(Tiversi b) Minnesota, Minneapolis, Minnesota, USA

Received 25 October 2005; accepied/3 October 2005

KEYWORDS
Guideline;
Respiratory diseases;
Primary care;
General practice;
Diagnosis;
Rhinitis;
Asthma;
COPD;
Symptoms;
Questionnaires

KEYWORDS

Guideline;

Respiratory diseases;

Primary care;

General practice;

Diagnosis;

Rhinitis;

Asthma;

Symptoms;

Questionnaires

\begin{abstract}
Summary This Diagnosis paper constitutes the second of the IPCRG Guideline papers on the management of chronic respiratory diseases in primary care. Primary care health professionals are usually the first point of contact for patients who can present a wide range of initial symptoms which may or may not constitute their first presentation of a chronic disease such as asthma, COPD, or rhinitis. This paper is focussed upon the early identification and diagnosis of chronic respiratory diseases in primary care. It uses a symptom-based approach, and includes original questionnaires and diagnostic guides to help the primary care clinician proceed systematically through the diagnostic process.

(C) 2005 Published by Elsevier Ltd on behalf of General Practice Airways Group.
\end{abstract}

\footnotetext{
* Corresponding author. Tel.: +44 (0) 1316514151 ;

fax: +44 (0) 1316509119.

E-mail address: marklevy@animalswild.com (M.L. Levy).
}

\section{Background}

Primary care physicians treat the majority of patients with respiratory diseases. However, in most countries, specific primary care guidelines are not available. Since clinical management which follows evidence-based guidelines yields better 
Three Star System of the Royal College of General Practitioners:

\begin{tabular}{|c|c|}
\hline Evidence Base & $\begin{array}{l}\text { Royal College of General } \\
\text { Practitioners. The } \\
\text { development and } \\
\text { implementation of } \\
\text { clinical guidelines. } \\
\text { Report of the clinical } \\
\text { guidelines working group. } \\
\text { London, 1995, RCGP [5]. }\end{array}$ \\
\hline${ }^{* * *}$ Strong evidence & $\begin{array}{l}\text { Provided by generally } \\
\text { consistent findings in } \\
\text { multiple, high quality } \\
\text { scientific studies. }\end{array}$ \\
\hline${ }^{* *}$ Moderate evidence & $\begin{array}{l}\text { Provided by generally } \\
\text { consistent findings in } \\
\text { fewer, smaller or } \\
\text { lower-quality scientific } \\
\text { studies. }\end{array}$ \\
\hline " Limited evidence & $\begin{array}{l}\text { Provided by one scientific } \\
\text { study or inconsistent } \\
\text { findings in multiple } \\
\text { scientific studies. }\end{array}$ \\
\hline - No scientific evidence & $\begin{array}{l}\text { Based on clinical studies, } \\
\text { theoretical } \\
\text { considerations and/or } \\
\text { clinical consensus. }\end{array}$ \\
\hline
\end{tabular}

results for patients, it is important torayeaccess to primary care guideling which are specifically relevant to, ind bicy ded by, primary lace. The International Primary Care FE; pi-atory Group (IPCRG) asked primary care experts from several countries to develop primary care guidelines for the diagnosis and treatment of asthma, chronic obstructive pulmonary disease (COPD) and rhinitis. A brief summary of the expert report (which took three years to complete) was published as a handbook [1] in 2005.

This paper is devoted to the diagnosis of chronic respiratory disease in primary care and is specifically written for primary care health professionals. In addition to this diagnosis section, the IPCRG guidelines consist of papers on the management of COPD [2], asthma [3], and rhinitis [4]. For the purpose of ranking the evidence in each of these publications we have used the so-called Three Star System of the Royal College of General Practitioners [5] in order to score the evidence of the statements made (see box).

\section{Introduction}

Health professionals in primary care are usually the first point of contact for people presenting with a wide range of health concerns. Patients present to their family doctor or nurse with a wide spectrum of problems ranging from diagnosed and treated chronic illnesses to poorly differentiated early symptoms which may or may not constitute their first presentation of a chronic disease such as asthma or diabetes. The challenge for primary care clinicians is to determine whether or not the new symptoms represent a life-threatening emergency, a short-term problem likely to resolve spontaneously, or an evolving chronic health condition. Unfortunately, patients in primary care do not consult with a partial or complete diagnosis, as is often the case by the time patients are seen in secondary care. Table 1 lists some examples of the respiratory diseases for which patients may consult a primary care health professional.

After identifying and dealing with emergency conditions, most other respiratory symptoms can be evaluated by primary care physicians or nurses over a number of short (6 to $12 \mathrm{~min}$ ) consultations. Primary care physicians seldom have the opportunity for the lengthy in-depth diagnostic assessment common in secondary/specialty care. As a result, patients are initial(y) treated symptomatically in the Sabsence of a clear diagnosis whilst the diagnostic process evolves [6] Conversely, the primary care diagnostic process is often tol tered by prior knowledge of the? (Datient gained over numerous previous consultations within primary care.

This paper, part of the IPCRG Guideline, is focused upon the early identification and diagnosis of patients with chronic respiratory conditions presenting in the primary care setting. Since the availability of diagnostic resources in primary care is limited in many regions of the world, a symptom-based approach is used. However, whenever possible, lung function testing using spirometry $[7,8]^{* * *}$ and peak expiratory flow (PEF) measurements is required to make a clear diagnosis $[9,10]^{* * *},[11]^{*}$

Diagnosing chronic airways disease early in primary care depends upon early recognition of suggestive symptoms. To assist this process, a series of questionnaires have been developed based on questions identified in the research literature. Some of these have been published elsewhere [1] as has the background methodology for their development [12-16]. These core diagnostic assessment questions are intended to facilitate structured history-taking, and to supplement a complete patient history and physical examination. These Questionnaires, paired with a series of Diagnosis Guides, are presented in this paper to help the primary care clinician proceed 
Table 1 Overview of lung diseases to be considered by primary care health professionals when consulted by patients

\begin{tabular}{ll}
\hline LUNG DISEASES that patients present with in primary care consist of: \\
\hline INFECTIONS (ranging from mild to severe), e.g.: Simple colds, other viral and bacterial infections such as \\
bronchiolitis, influenza, pneumonia, tuberculosis, HIV/AIDS, and related opportunist infections \\
Malignancies (primary and secondary) and; \\
\hline OBSTRUCTIVE DISEASES & RESTRICTIVE DISORDERS \\
Generalized & Lung disease \\
Chronic obstructive pulmonary disease (COPD) & Extrinsic allergic alveolitis \\
Asthma & Sarcoidosis \\
Obliterative bronchiolitis & Fibrosing alveolitis \\
Cystic fibrosis & Asbestosis \\
& Eosinophilic pneumonia \\
Localized & Pleural disease \\
Vocal cord paresis & Pleural effusion \\
Laryngeal carcinoma & Pneumothorax \\
Tracheal carcinoma & Bronchiectasis \\
Bronchial carcinoma & Chest wall deformity \\
Foreign bodies & Kyphoscoliosis \\
Bronchopulmonary dysplasia & Respiratory muscle weakness \\
& Subdiaphragmatic problems \\
& Obesity \\
& Ascites \\
\hline
\end{tabular}

systematically through the diagnostic process. However, the Questionnaires and Diagnosis Guides in this section are not intended to guarantee a diagnosis nor are they a substitute for cliricat judgment. Rather, the tools proviced fl ou.d raise the clinician's awarenless that the patient naj be suffering irom a conic rather thar ahd acute illness. Fatients for whom aciaghosis remains in doubt after using the approach presented here should be strongly considered for referral to a site with additional diagnostic options including pulmonary function testing and specialist evaluation. Table 2 summarises the stages involved in diagnosing respiratory disease in primary care.

1. Characterize the Problem-see Figure 1 Common presenting symptoms of airways disease are:

- Cough

- Wheeze

- Breathlessness

- Shortness of breath

- Chest tightness

Table 2 Stages of diagnosing respiratory disease in primary care

1. Characterise the problem:

a. Exclude infectious diseases

b. Exclude non-respiratory causes

c. Establish if chronic condition

2. Consider the patient's age and related illnesses

3. Investigate possible chronic airways diseases
- Runny, blocked or itchy noise UO

- Limitation of Rualactivities

ire 0 ou

These symptoms may be exacerbated by exercise ancin er oswe to irritants or allergens. $[7-1 / 0,17-19]^{* * 1}$ If a patient's history is consistent with respiratory disease, the problem may be characterized further in these three ways:

\section{a. Exclude Infectious Diseases}

Chronic respiratory infections may produce symptoms similar to those described above. Tuberculosis, HIV, and fungal or parasitic infections may be common causes of chronic respiratory symptoms in some parts of the world. A "yes" answer to any of the following should raise suspicion of a chronic infectious process:

- Does the patient have fever, chills or sweats?

- Is the patient losing weight? (e.g. Tuberculosis; Cystic fibrosis may be manifested by failure to thrive)

- Does the patient produce purulent sputum, or have a purulent nasal discharge?

- Does the patient live in, or has the patient immigrated from, an area with high rates of HIV or TB?

\section{b. Exclude Non-Respiratory Causes}

A "yes" answer to any of the following questions suggests a non-respiratory origin or exacerbation in anyone aged 6 years and older: 


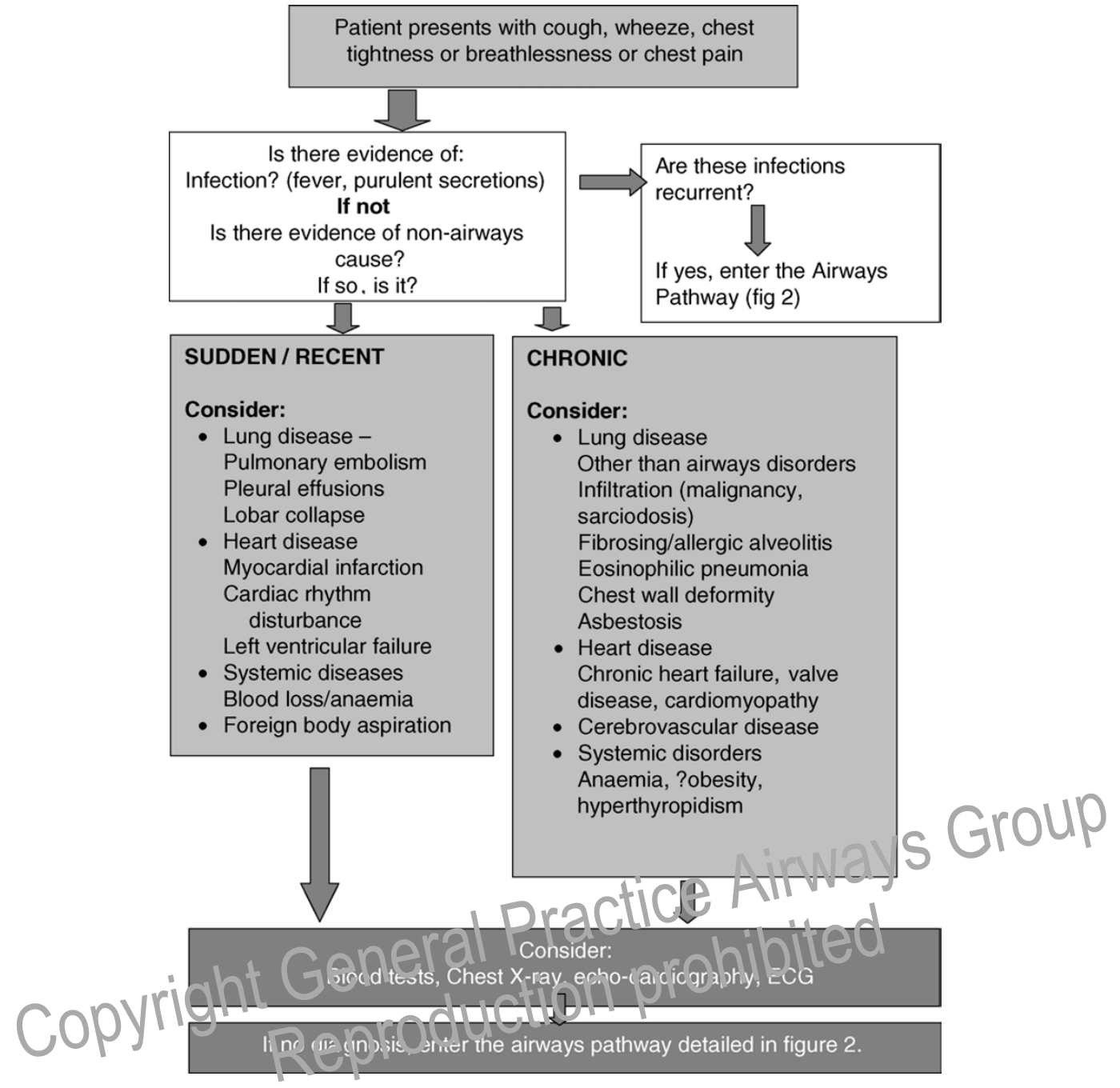

Figure 1 Respiratory symptoms: Initial differentiation in diagnosing airways disease.

- Is there evidence of heart disease? (Chest pain, palpitations, oedema, cardiac murmers)

- Is there evidence of gastrointestinal reflux - gastrointestinal disease can co-exist with and also act as a trigger factor for asthma, especially in children. (Indigestion, heartburn) $[17,18,20,21]^{* * *}[22]$

- Are there signs of systemic disease? (anaemia, recent weight loss, haemoptysis)

Consider malignancy or tuberculosis in patients with a history of systemic illness plus haemoptysis, and consider referring patients without a clear diagnosis to a specialist.

For children under 6, refer to Figure 2 and Tables 5-7.

c. Establish chronicity

A "yes" answer to any of these questions suggests the respiratory problem is chronic: $[7-10,17,18]^{* * *}$
- Does the patient have symptoms most months of the year?

- Does the patient have symptoms most days in some months of the year?

- Do the symptoms recur regularly?

- If so; is the pattern regular? (seasonal or monthly) or is it based on other problems? (exposure to irritants in the workplace, acute infections)

Typically asthma is characterized by variable, intermittent symptoms. $[9,10]^{* * *}$

2. Consider the Patient's Age

The epidemiology of airways diseases is strongly correlated with age and therefore establishing the patient's age is intrinsic to a practical initial approach to diagnosis;

- Children under 6: Consider asthma. Asthma is primarily a diagnosis of exclusion in this age group since objective lung function testing 

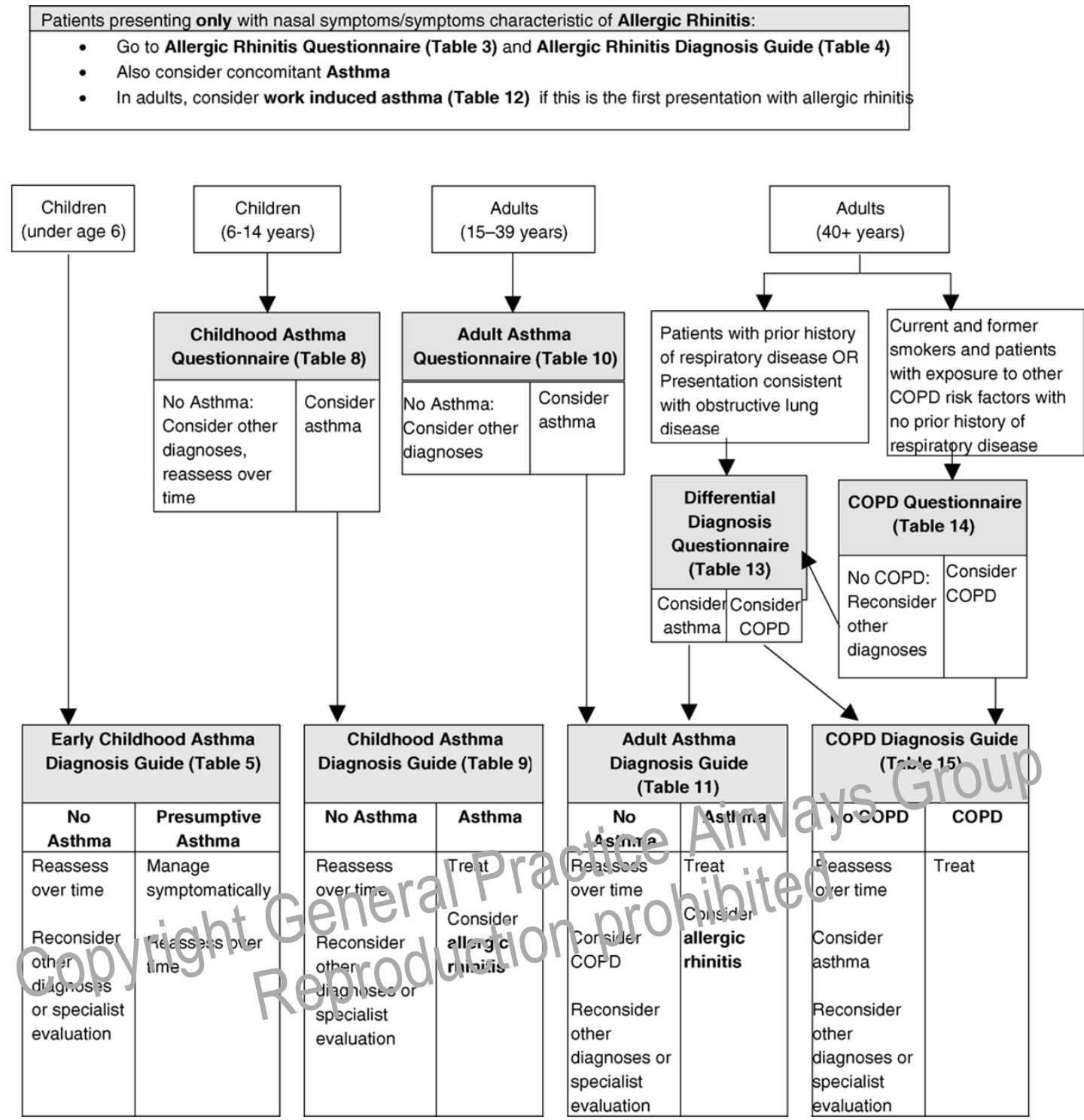

Figure 2 Diagnosis of Chronic Respiratory Diseases in primary care.

is difficult. Allergic rhinitis is unlikely, and is difficult to diagnose, in children below 3-4 years of age. Food allergy rather than inhalant allergy is the main problem under the age of 5 and vice versa over the age of $5 .[23]^{* *}$ Congenital conditions such as previous unrecognized heart defects, cystic fibrosis, or lung disease associated with marked prematurity must be considered.

- Children 6-14: Asthma and allergic rhinitis are the predominant airways diseases. Any child with allergic rhinitis should also be evaluated for asthma, and vice versa $[17,18]^{* \star *}[24,25]^{*}$. Previously unrecognised congenital heart disease is still possible.

- Adults 15-39: Asthma and allergic rhinitis remain common airways diseases in this age range. Any patient with allergic rhinitis should be evaluated for asthma, and vice versa. Consider work-induced asthma in adults with new symptoms (i.e. occupational asthma) or work-aggravated asthma in adults with known asthma who have a recurrence or exacerbation of symptoms. See Table 12 $[26-28][29]^{* * *}$

- Adults $\mathbf{4 0}$ and over: COPD becomes the predominant chronic airways disease, especially in adults with previous tobacco exposure, and it must be considered in both men and women. However, asthma and allergic rhinitis still occur. A key challenge in this age group is distinguishing asthma from COPD; patients' risk factors (especially exposure to tobacco smoke or other noxious 
Table 3 Allergic Rhinitis Questionnaire $[17,18,30]^{* * *}$

Start by referring to the flow chart in Figure 2, and asking these questions:

1. Do you have any of the following symptoms:

- Symptoms on only one side of your nose

- Nasal obstruction without other symptoms

- Thick, green or yellow discharge from your nose

- Postnasal drip (down the back of your throat) with thick mucus and/or no runny nose

- Facial pain

- Recurrent nosebleeds

- Inability to smell

2. Do you have any of the following symptoms for at least one hour on most days (or on most days during the season if your symptoms are seasonal)?

- Watery runny nose

- Sneezing, especially violent and in bouts

- Nasal obstruction

- Nasal itching

- Conjunctivitis (red, itchy eyes)

Scoring System: The presence of watery runny nose with ONE OR MORE of the other symptoms in this list suggests allergic rhinitis, and indicates that the patient should undergo further diagnostic assessment.

NOTE: Any patient diagnosed with allergic rhinitis should also be evaluated for asthma.

\# These symptoms are usually NOT found in allergic rhinitis and the presence of ANY ONE of them suggests that alternative diagnoses should be investigated.

fumes at home or work, or chronic exposure to biomass fuel fires) and a history of prior respiratory disease helps guide diagnostic evaluation. Distinguishing the two requires appropriate lung function testing with hos:bronchodilator evaluation for Clefinitive. diagnosis, butr "laking la sood history and

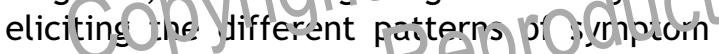
presentation go a long wa, to establishing the correct diagnosis.

Acute or chronic infection(s) or an acute event due to respiratory or cardiac disease, or a systemic condition must be considered. Other lung diseases involving areas other than the airways must also be considered, as should respiratory effects of cardiovascular or systemic disease. Chest radiography and electrocarcicaslaphy, and more sophisticateci im ag houch as CT and MRI scanning, echb:-Ar(iii)g laphy and angiography, may be needed a.c ciagnose spme of these conditions. Figure 1 illustrates: ompof the conditions that need to be cons dered when patients present with respiratory symptoms.

\section{Investigate a Specific Diagnosis or diagnoses}

Having characterized the patient's problem as being possibly due to an underlying chronic airways

Table 4 Allergic Rhinitis Diagnosis Guide $[17,18,30]^{* * *}$

Diagnostic Tool
Physical examination
Trial of therapy
In persistent rhinitis:
- Anterior rhinoscopy using speculum and mirror
gives limited information
- Nasal endoscopy (usually performed by specialist)
may be needed to exclude other causes of rhinitis,
nasal polyps, and anatomic abnormalities
Allergy skin testing or serum specific lgE

Findings that Support Diagnosis

Transverse crease of nose, allergic "shiners." (i.e. looks like bruising of eye)

Improvement with antihistamines or intranasal glucocorticosteroid.

Exclusion of other causes. 
Table 5 Early Childhood (under age 6) Asthma Diagnosis Guide $[9,10]^{* * * *}$

\begin{tabular}{ll}
\hline Differential diagnosis & Findings that Support Diagnosis \\
& $\begin{array}{l}\text { - The diagnosis of asthma in children under } 6 \text { is primarily one of } \\
\text { exclusion, and the differential diagnosis is substantially different from } \\
\text { that in older children. } \\
\text { - In general, the younger the child, the greater the likelihood that an } \\
\text { alternative diagnosis may explain recurrent wheeze. } \\
\text { - Table } 6 \text { summarises alternative diagnoses to consider in young } \\
\text { children, and Table } 7 \text { provides characteristic symptoms of each. } \\
\text { - Once other conditions are ruled out, asthma should be considered } \\
\text { the presumptive cause of wheezing. }\end{array}$ \\
Improvement with bronchodilators or with trial of glucocorticosteroid \\
thial of therapy & $\begin{array}{l}\text { Exclude other causes of wheezing, such as focal lung findings, } \\
\text { pulmonary or cardiac malformation, or foreign body. }\end{array}$ \\
Chest X-ray & $\begin{array}{l}\text { Variation in peak flow over 20\% or FEV1 over 15\% is strongly suggestive } \\
\text { of asthma }\end{array}$ \\
Lung function testing when child is & - Confirm presence of atopy (high false negative rate under age 3). \\
old enough to perform test &
\end{tabular}

disease, the flow chart in Figure 2 enables a structured pathway to diagnosis by starting with a questionnaire appropriate for the patient's age and then using information within a diagnosis guide: wheezing, go directly to the Diagnosis Guide, Table 5)

- Based cioon the parients responses to the + Questiolmailes, continue to the most appropriate Diagnosis Guide

- Begin with the patient's age and preetention

- Choose the most tepropriatel Questionnaire (in enildren Under age 6 with declirent Reproro

V'hen a patient consults for chronic or recurrent nasal symptoms or for asthma, a standardised

Table 6 Differential Diagnosis of Young Children Presenting with Wheezing [31]

\begin{tabular}{|c|c|c|c|c|}
\hline Age & Common & Uncommon \& Recurrent & Uncommon & Rare \\
\hline Less than 6 months & $\begin{array}{l}\text { Bronchiolitis } \\
\text { Gastro-esophageal } \\
\text { reflux }\end{array}$ & $\begin{array}{l}\text { Aspiration pneumonia* } \\
\text { Bronchopulmonary dysplasia } \\
\text { Congestive heart failure } \\
\text { Cystic fibrosis }\end{array}$ & & $\begin{array}{l}\text { Asthma } \\
\text { Foreign body } \\
\text { aspiration }\end{array}$ \\
\hline 6 months -2 years & $\begin{array}{l}\text { Bronchiolitis } \\
\text { Foreign body } \\
\text { aspiration }\end{array}$ & $\begin{array}{l}\text { Aspiration pneumonia* } \\
\text { Asthma } \\
\text { Bronchopulmonary dysplasia } \\
\text { Cystic fibrosis } \\
\text { Gastro-esophageal reflux }\end{array}$ & & $\begin{array}{l}\text { Congestive heart } \\
\text { failure }\end{array}$ \\
\hline $2-5$ years & $\begin{array}{l}\text { Asthma } \\
\text { Foreign body } \\
\text { aspiration }\end{array}$ & & $\begin{array}{l}\text { Cystic fibrosis } \\
\text { Gastro-esophageal } \\
\text { reflux } \\
\text { Viral pneumonia }\end{array}$ & $\begin{array}{l}\text { Aspiration } \\
\text { pneumonia* } \\
\text { Bronchiolitis } \\
\text { Congestive heart } \\
\text { failure } \\
\text { Gastro-esophageal } \\
\text { reflux }\end{array}$ \\
\hline
\end{tabular}

"May be secondary to gastro-esophageal reflux, transient or permanent uncoordinated swallowing or, rarely, tracheo-esophageal fistula. 
Table 7 Clues to Alternative Diagnoses in Wheezy Children (features not commonly found in asthma). Adapted from: British Thoracic Society; Scottish Intercollegiate Guidelines Network

\begin{tabular}{|c|c|}
\hline Clinical Clue & Possible D \\
\hline \multicolumn{2}{|l|}{ Perinatal and family history } \\
\hline $\begin{array}{l}\text { Symptoms present from birth or } \\
\text { perinatal lung problem }\end{array}$ & $\begin{array}{l}\text { Cystic fibrosis; ciliary dyskinesia; developmental anomaly, } \\
\text { bronchopulmonary dysplasia }\end{array}$ \\
\hline $\begin{array}{l}\text { Family history of unusual lung } \\
\text { disease }\end{array}$ & Cystic fibrosis; developmental anomaly; neuromuscular disorder \\
\hline $\begin{array}{l}\text { Severe upper respiratory tract } \\
\text { disease }\end{array}$ & Primary immune deficiency \\
\hline \multicolumn{2}{|l|}{ Symptoms and Signs } \\
\hline Persistent wet cough & $\begin{array}{l}\text { Cystic fibrosis; aspiration pneumonia; primary immune deficiency; } \\
\text { tuberculosis, bronchopulmonary dysplasia, congenital heart disease } \\
\text { with congestive failure }\end{array}$ \\
\hline $\begin{array}{l}\text { Excessive vomiting or "spitting } \\
\text { up" }\end{array}$ & Gastro-oesophageal reflux \\
\hline Dysphagia & Swallowing problems ( \pm aspiration) \\
\hline Abnormal voice or cry & Laryngeal problem \\
\hline Focal signs in the chest & $\begin{array}{l}\text { Developmental disease; postviral syndrome; bronchiectasis; } \\
\text { tuberculosis; foreign body aspiration }\end{array}$ \\
\hline Heart murmur & Congenital heart disease \\
\hline $\begin{array}{l}\text { Inspiratory stridor as well as } \\
\text { wheeze }\end{array}$ & Central airway or laryngeal disorder \\
\hline Failure to thrive & $\begin{array}{l}\text { Cystic fibrosis; primary immune deficiency; gastro-oesophageal reflux; } \\
\text { tuberculosis, bronchopulmonary dysplasia, congenital heart disease }\end{array}$ \\
\hline $\begin{array}{l}\text { Investigations } \\
\text { Focal or persistent radiological } \\
\text { changes }\end{array}$ & $\begin{array}{l}\text { Developmental disorder; } \text { Fost. in } 1 \in \text { ctive discrder; aspiration } \\
\text { pneumoria forign body a.spiration; bron hiectasis; tuberculosis }\end{array}$ \\
\hline \multicolumn{2}{|c|}{ 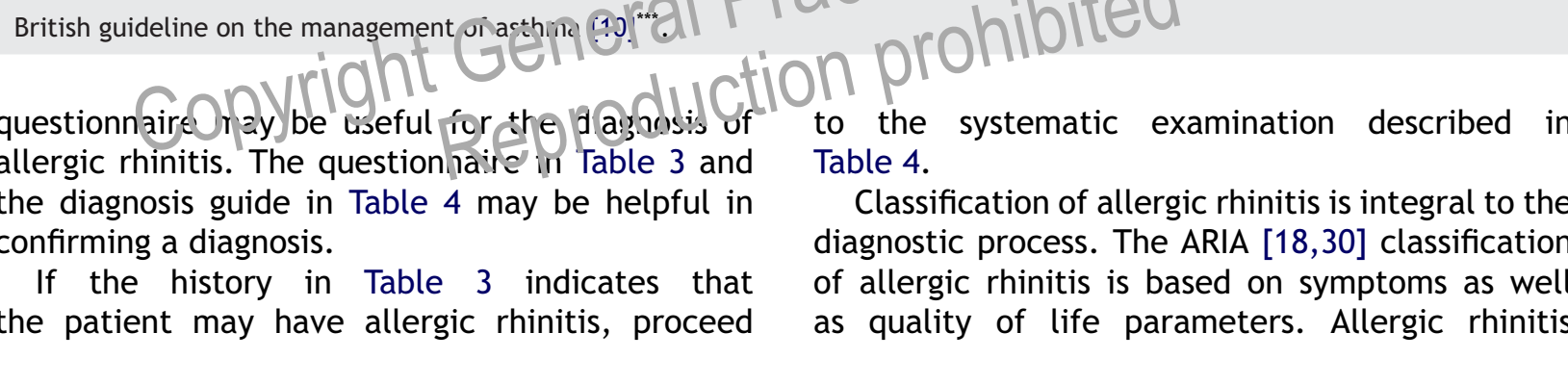 } \\
\hline
\end{tabular}

Table 8 Childhood Asthma Questionnaire [32-39]

1. Have you/has your child had wheezing or whistling in the chest in the last 12 months?

2. In the last 12 months, have you/has your child had a dry cough at night, apart from a cough associated with a cold or chest infection?

3. Do you/does your child have a history of hay fever or eczema?

4. Is there a family history of asthma in your (child's) first-degree relatives?

5. Have you/has your child received more than three courses of antibiotics for respiratory symptoms (both upper and lower respiratory tract) in the last 12 months?

6. In the last 12 months, has your (child's) chest sounded wheezy during or after exercise?

7. In the last 12 months, has your (child's) sleep been disturbed due to wheezing?

8. In the last 12 months, has wheezing ever been severe enough to limit your (child's) speech to only one or two words at a time between breaths?

9. In the last 12 months, have you/has your child been to a doctor, an emergency room, or a hospital for wheezing?

Scoring: A positive response to any of the questions above suggests an increased likelihood of asthma, and suggests that the patient should undergo further diagnostic assessment. Positive responses to 3 or more of the questions in bold suggest a greater than $90 \%$ likelihood of asthma.

NOTE: Any patient diagnosed with asthma should also be evaluated for allergic rhinitis. 
Table 9 Childhood Asthma Diagnosis Guide $[10,11,20]^{* * * *}$

\begin{tabular}{|c|c|}
\hline Diagnostic Tool & Findings that Support Diagnosis \\
\hline Physical examination & $\begin{array}{l}\text { - Expiratory wheeze on auscultation (may or may not be present). } \\
\text { - Increased expiratory time (may or may not be present). }\end{array}$ \\
\hline Trial of therapy & $\begin{array}{l}\text { Improvement with bronchodilators or with trial of glucocorticosteroid } \\
\text { therapy. }\end{array}$ \\
\hline \multirow{2}{*}{$\begin{array}{l}\text { Reversibility testing with } \\
\text { spirometry or PEF }\end{array}$} & Demonstration of reversible airflow limitation: \\
\hline & $\begin{array}{l}\text { - FEV1 improves at least } 12 \% \text { either spontaneously, after inhaled } \\
\text { bronchodilator, or after trial of glucocorticosteroid therapy; OR } \\
\text { - PEF improves at least } 20 \% \text { after inhaled bronchodilator or after trial } \\
\text { of glucocorticosteroid therapy. }\end{array}$ \\
\hline \multirow{2}{*}{$\begin{array}{l}\text { Exercise challenge with spirometry } \\
\text { or PEF }\end{array}$} & Demonstration of airway hyperresponsiveness: \\
\hline & $\begin{array}{l}\text { - FEV1 decreases at least } 12 \% \text { from baseline after } 6 \text { min of exercise; OR } \\
\text { - PEF decreases at least } 20 \% \text { from baseline after } 6 \text { min of exercise. } \\
\text { Note: some children with asthma present only with symptoms associated } \\
\text { with exercise. }\end{array}$ \\
\hline Home PEF diary & $\begin{array}{l}\text { Demonstration of variable airflow limitation: } \\
\text { - PEF varies more than } 20 \% \text { from morning measurement upon arising to } \\
\text { measurement } 12 \mathrm{~h} \text { later in patients taking a bronchodilator (more than } \\
10 \% \text { in patients not taking a bronchodilator). }\end{array}$ \\
\hline \multirow{2}{*}{$\begin{array}{l}\text { Allergy skin testing or serum } \\
\text { specific lgE }\end{array}$} & - Confirm presence of atopy. \\
\hline & - Specific triggers identified. \\
\hline
\end{tabular}

NOTE: Any patient diagnosed with asthma should also be evaluated for allergic rhinitis.

is classified by duration into "intermittent" or wh=ez-ng illness in children under the age of 6 "persistent" disease, and by severity inco "m ld"' d years.

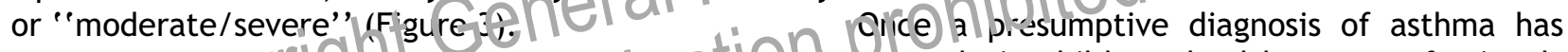

\section{Children}

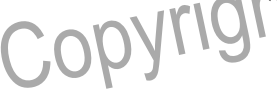

In the case of children presenting with recurrent respiratory symptoms, Tables 5-9 provide information and a series of questions that may be helpful in making a diagnosis or in deciding whom to refer for a specialist opinion.

Table 5 describes the features suggestive of asthma in children under the age of 6 years.

Table 6 has been adapted from Anbar RD and Lannuzzi DM [31] and is helpful in differentiating be made in children, health care professionals should always be prepared to reassess and, if necessary, reconsider the diagnosis if management is ineffective or if the clinical situation changes. Many young children who wheeze with viral respiratory infections may benefit from asthma medication for their wheezing episodes, but not all will develop asthma that persists through childhood. In Table 7, we detail the clues to alternative diagnoses other than asthma in children presenting with wheezing illness.

Having excluded other diseases in children, Table 8 provides a series of evidence-based

Table 10 Adult Asthma Questionnaire [38-42]"*

1. Have you had wheezing or whistling in your chest at any time in the last 12 months?

2. Have you been woken up at night by an attack of coughing at any time in the last 12 months?

3. Have you been woken up at night by an attack of shortness of breath at any time in the last 12 months?

4. Have you woken up with a feeling of tightness in your chest at any time in the last 12 months?

If new or recurrent asthma or rhinitis is suspected, assess possible occupational association: ${ }^{\text {*t* }}$ [22-24], [29]

5. Do your symptoms occur less frequently or not at all on days away from work and on vacations?

If yes, ask about the nature of the patient's occupation and consider 4-hourly peak flow recording at and away from work and consider referring patient to a specialist for further assessment. (see Table 12) 
questions derived from published literature that are useful in identifying possible asthma. Ask the questions in the table. Depending on the child's age, questions can be asked directly of the child $(13-14)$ or directed to parents/caregivers $(6-12)$. Given the intermittent nature of asthma symptoms, these questions should be asked over time to establish a diagnosis of asthma. Positive responses to three or more of the questions marked in bold suggest a greater than $90 \%$ likelihood of asthma. If responses suggest asthma, proceed with the suggested investigations detailed in the Childhood Asthma Diagnosis Guide - Table 9.

\section{Adults}

In adults suffering from chronic respiratory symptoms, three questions predominate for health professionals in primary care. (i) Has this person got asthma? (ii) if so, is this due to occupational exposure? and (iii) has the person got Chronic Obstructive Pulmonary Disease (COPD)?

The questionnaire in Table 10, and diagnosis guide in Table 11, may be helpful in identifying those adults presenting with respiratory or nasal symptoms who may have asthma. Table 12 highlights the main features and screening method for diagnosing work-related or occupational asthma. Ask the patient the questions listed in Table 10. A positive response to any of the questions in this table suggests an increased likelihood of asthma, and suggests that the patient should undergo further diagnostic assessment. If responses suggest asthma, proceed as detailed in Table 11. Given the intermittent nature of asthma symptoms, these questions should be asked over time to establish a diagnosis of asthma.

Table 11 Adult Asthma Diagnosis Guide [7-10] ${ }^{* * *}$

\begin{tabular}{|c|c|}
\hline & Findings that Support Diagnosis of asthma \\
\hline History & 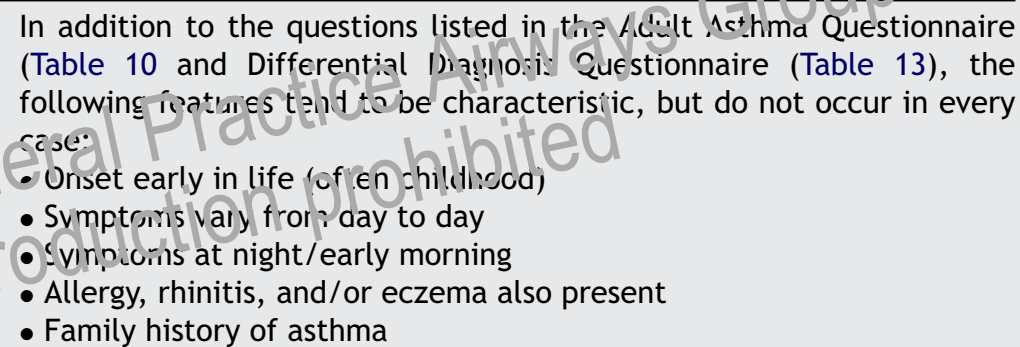 \\
\hline Physical examination & $\begin{array}{l}\text { - Expiratory wheeze on auscultation (may or may not be present). } \\
\text { - Increased expiratory time (may or may not be present). } \\
\text { - Hyperinflation (may or may not be present). }\end{array}$ \\
\hline Trial of therapy & $\begin{array}{l}\text { Improvement with bronchodilators or with trial of glucocorticosteroid } \\
\text { therapy. }\end{array}$ \\
\hline $\begin{array}{l}\text { Reversibility testing with } \\
\text { spirometry or PEF }\end{array}$ & Demonstration of reversible airflow limitation: \\
\hline & $\begin{array}{l}\text { - FEV1 improves at least } 12 \% \text { and } 200 \mathrm{~mL} \text { either spontaneously, after } \\
\text { inhaled bronchodilator, or after trial of glucocorticosteroid therapy; OR } \\
\text { - PEF improves at least } 20 \% \text { after inhaled bronchodilator or after trial } \\
\text { of glucocorticosteroid therapy. } \\
\text { (Note: Postbronchodilator FEV1/FVC }<0.70 \text { suggests COPD.) }\end{array}$ \\
\hline $\begin{array}{l}\text { Exercise challenge with spirometry } \\
\text { or PEF }\end{array}$ & Demonstration of airway hyper-responsiveness: \\
\hline & $\begin{array}{l}\text { - FEV1 decreases at least } 15 \% \text { from baseline after } 6 \text { min of exercise; OR } \\
\text { - PEF decreases at least } 20 \% \text { from baseline after } 6 \text { min of exercise. }\end{array}$ \\
\hline Home PEF diary & $\begin{array}{l}\text { Demonstration of variable airflow limitation: } \\
\text { - PEF varies more than } 20 \% \text { from morning measurement upon arising to } \\
\text { measurement } 12 \mathrm{~h} \text { later in patients taking a bronchodilator (more than } \\
10 \% \text { in patients not taking a bronchodilator). }\end{array}$ \\
\hline $\begin{array}{l}\text { Allergy skin testing or serum } \\
\text { specific IgE }\end{array}$ & $\begin{array}{l}\text { - Confirm presence of atopy. } \\
\text { - Specific triggers identified. }\end{array}$ \\
\hline
\end{tabular}

NOTE: Any patient diagnosed with asthma should also be evaluated for allergic rhinitis. 
Table 12 Work-related Asthma Diagnosis Guide: [29]

\begin{tabular}{|c|c|}
\hline \multicolumn{2}{|c|}{$\begin{array}{l}\text { Definitions: }[29,43] \\
\text { Work-related asthma = any case of asthma where there is an association between symptoms and work, } \\
\text { including } \\
\text { - Work-aggravated Asthma = Pre-existing or coincidental new onset adult asthma worsened by workplace } \\
\text { exposure, and } \\
\text { - Occupational asthma as defined by the United Kingdom Health and Safety Executive: 'Asthma which is } \\
\text { caused by workers breathing in substances at work that produce a hypersensitive state in the airways - } \\
\text { the small tubes that carry air in and out of the lungs - and trigger a subsequent response in them'. }\end{array}$} \\
\hline History & $\begin{array}{l}\text { Ask any adult patient with rhinitis or asthma, which is new, recurrent } \\
\text { or deteriorating, about their job, the materials with which they work } \\
\text { and whether their symptoms improve regularly when away from work. } \\
\text { If they do improve away from work, a diagnosis of work-related asthma } \\
\text { (or rhinitis) is possible. }\end{array}$ \\
\hline $\begin{array}{l}\text { History: common occupational } \\
\text { asthmagens }\end{array}$ & $\begin{array}{l}\text { The most frequently reported agents include: } \\
\text { - isocyanates } \\
\text { - flour and grain dust } \\
\text { - colophony and fluxes } \\
\text { - latex } \\
\text { - animals } \\
\text { - aldehydes } \\
\text { - wood dust }\end{array}$ \\
\hline Peak Flow Diary charts & $\begin{array}{l}\text { Arange for people suspected of having occupational asthma to perform } \\
\text { serial peak flow measurements at least four times a day. } \\
\text { If the readings on rest days away from work are highen ha on work } \\
\text { days, and there is variation }>20 \% \text {, consider referi in, the patient to an } \\
\text { occupational medicine specialist. }\end{array}$ \\
\hline
\end{tabular}

\section{".ht General}

Having Estabished thit andouct patient possibly has asthma by asring the questions in Tables 10 and 13, the investigations detailed in Table 11 may be helpful in confirming the diagnosis. For those patients suspected of having occupational or work-aggravated asthma, proceed with the Work-related Asthma Diagnosis Guide detailed in Table 12 [26-28,29] ${ }^{* * *}$.

\section{Occupational asthma}

Exposure to factors at work contributes to 9-15\% of cases of adult asthma [29] $]^{* * *}$ Any adult with new-onset asthma or whose symptoms of asthma have worsened since starting a new job may have occupational asthma. This constitutes the only potentially curable form of asthma, provided the condition is diagnosed early and further exposure to the cause is avoided.

Work-related asthma is under-diagnosed and therefore under-treated [26-28],[29] ${ }^{* * *}$. Table 12 details how these patients may be identified earlier.

\section{Differentiating asthma from COPD}

One of the major challenges for primary care health professionals lies in differentiating asthma from COPD. Tables 13 and 14 detail two original questionnaires developed for the purpose of this diagnosis guideline. The background process of development of these questionnaires is detailed elsewhere [14-16]. These questionnaires are intended for use in primary care, for patients presenting with respiratory symptoms. Clinicians may wish to ask their patients to complete the questionnaires either before or during the consultation.

The questionnaire in Table 13 may be useful in differentiating asthma from COPD. It is intended for use in adults age 40 or older who have a prior diagnosis of respiratory disease and/or are on regular treatment for respiratory symptoms. The scoring system is provided in the box below the table.

The questionnaire in Table 14 may be useful in identifying previously undiagnosed patients who are suffering from COPD. It is intended 
Table 13 Differential Diagnosis Questionnaire: [16]

\begin{tabular}{|c|c|c|}
\hline & Response Choices & Points \\
\hline \multirow[t]{3}{*}{ What is your age? } & $40-49$ years & 0 \\
\hline & $50-59$ yrs & 5 \\
\hline & $60-69$ years & 9 \\
\hline How many pack years of cigarettes have you smoked? & $0-14$ pack years & 0 \\
\hline To calculate pack years: & 15-24 pack years & 3 \\
\hline Packs per day $=$ number of cigarettes per day $/ 20$ & 25-49 pack years & 7 \\
\hline $\begin{array}{l}\text { Pack years }=\text { packs per day } \times \text { number of years smoked (e.g. } 10 \text { a day } \\
\text { for } 20 \text { years }=10 / 20=1 / 2 \text { pack } \times 20 \text { yrs }=10 \text { pack years) }\end{array}$ & $50+$ pack years & 9 \\
\hline \multirow[t]{2}{*}{ Have you coughed more in the last few years? } & Yes & 0 \\
\hline & No & 1 \\
\hline \multirow{2}{*}{$\begin{array}{l}\text { During the past } 3 \text { years, have you had any breathing problems that } \\
\text { have kept you off work, indoors, at home, or in bed? }\end{array}$} & Yes & 0 \\
\hline & No & 3 \\
\hline \multirow[t]{2}{*}{ Have you ever been admitted to the hospital with breathing problems? } & Yes & 6 \\
\hline & No & 0 \\
\hline \multirow[t]{2}{*}{ Have you been short of breath more often in the past few years? } & Yes & 1 \\
\hline & No & 0 \\
\hline \multirow[t]{2}{*}{ On average, how much phlegm (sputum) do you cough up most days? } & $\begin{array}{l}\text { None or less than } 1 \text { Tablespoon } \\
(15 \mathrm{ml} \text { or } 1 / 2 \mathrm{oz}) \text { per day }\end{array}$ & 0 \\
\hline & $\begin{array}{l}1 \text { Tablespoon }(15 \mathrm{ml} \text { or } 1 / 2 \mathrm{oz}) \text { or } \\
\text { more per day }\end{array}$ & 4 \\
\hline \multirow{4}{*}{$\begin{array}{l}\text { If you get a cold, does it usually go to your chest? } \\
\text { Are you taking any treatment to help your breathing? } \\
\text { "Yes"' suggests COPD. }\end{array}$} & Yes & 4 \\
\hline & No & 0 \\
\hline & 5 & 5 \\
\hline & & 0 \\
\hline
\end{tabular}

Scoring Syşer tol the differenial diogn nos is f lusstionnaire: $[44,45]$

Add up the total number of poin:- azs $=\mathrm{d}$ on the patient's response.

- 18 or fewer points suggests a diagnosis of asthma; in this case go to the adult asthma diagnosis guides (Tables 11 and 12)

- 19 or more points suggests a diagnosis of COPD, and in this case go to Table 15

Asthma and COPD may co-exist in some patients since they are two separate respiratory diseases with differing pathology, aetiologies and natural histories. Whilst these patients are likely to score 19 or more points, if asthma is also suspected a reversibility test should be performed. An increase in FEV1 of more than $12 \%$ and at least $200 \mathrm{mls}[7]^{*+*}$ indicates a diagnosis of asthma. (400 $\mathrm{mls}$ - according to the NICE Guidelines [8] $]^{\text {tw** }}$ )

for use in adults age 40 or older who have a history of smoking or exposure to other COPD risk factors (occupational dusts and chemicals or smoke from home cooking and heating fuel)* AND who have no prior diagnosis of respiratory disease.

Table 15 COPD Diagnostic guide: $[7,8]^{* * *}$ summarises the steps to be taken in primary care in confirming a diagnosis of COPD, or identifying those who may benefit from a specialist opinion. Note the difference in reversibility criteria according to two sets of guidelines.
Patients who have a history of exposure to risk factors and chronic symptoms, but normal spirometry, are considered "at risk" for COPD. Although not all patients "at risk" will go on to develop COPD, all should be given intensive intervention to reduce exposure to risk factors and prevent progression of the disease $[8]^{* * *}$.

Whilst the questionnaires and diagnostic guides in this paper may help to confirm a diagnosis in many patients with respiratory symptoms, a specialist should be consulted if there remains any doubt, or if the patient does not respond as expected to therapy. 
Table 14 COPD Questionnaire, to be used in patients presenting with a history suggestive of COPD and who are not suspected of having asthma [15]

\begin{tabular}{|c|c|c|}
\hline & & Points \\
\hline What is your age? & $\begin{array}{l}40-49 \text { yrs } \\
50-59 \text { yrs } \\
60-69 \text { yrs } \\
70 \text { years or older }\end{array}$ & $\begin{array}{l}0 \\
4 \\
8 \\
10\end{array}$ \\
\hline What is your height in meters? & $\mathrm{BMI}<25.4$ & 5 \\
\hline What is your weight in kilogrammes? & BMI 25.4-29.7 & 1 \\
\hline $\begin{array}{l}\text { Calculate the } \mathrm{BMI}=\text { weight in } \mathrm{kg} /(\text { height in meters })^{2} \text { or } \mathrm{BMI}=[\text { Weight } \\
\left.\text { in pounds } /(\text { Height in inches })^{2}\right] \times 703\end{array}$ & BMI $>29.7$ & 0 \\
\hline How many pack years of cigarettes have you smoked? & $\begin{array}{l}0-14 \text { pack years } \\
15-24 \text { pack years }\end{array}$ & $\begin{array}{l}0 \\
2\end{array}$ \\
\hline To calculate pack years: & $25-49$ pack years & 3 \\
\hline $\begin{array}{l}\text { Packs per day }=\text { number of cigarettes per day } / 20 \\
\text { Pack years }=\text { packs per day } \times \text { number of years smoked (e.g. } 10 \text { a day } \\
\text { for } 20 \text { years }=10 / 20=1 / 2 \text { pack } \times 20 \text { yrs }=10 \text { pack years) }\end{array}$ & $50+$ pack years & 7 \\
\hline Does the weather affect your cough? & $\begin{array}{l}\text { Yes } \\
\text { No }\end{array}$ & $\begin{array}{l}3 \\
0\end{array}$ \\
\hline $\begin{array}{l}\text { Do you ever cough up phlegm from your chest, when you don't have } \\
\text { a cold? }\end{array}$ & Yes & 3 \\
\hline & No & 0 \\
\hline $\begin{array}{l}\text { Do you usually cough up phlegm (sputum) from your chest first thing } \\
\text { in the morning? }\end{array}$ & $\begin{array}{l}\text { Yes } \\
\text { No }\end{array}$ & $\begin{array}{l}0 \\
3\end{array}$ \\
\hline $\begin{array}{l}\text { How frequently do you wheeze? } \\
\text { "Occasionally" or "often" suggests COPD. }\end{array}$ & occasionally or more often & $\begin{array}{l}0 \\
4\end{array}$ \\
\hline $\begin{array}{l}\text { Do you have or have you had anv allergife? } \\
\text { "No" suggests COPD. }\end{array}$ & & $\begin{array}{l}0 \\
3\end{array}$ \\
\hline
\end{tabular}

Scoring System for the COPD questionnaire: [44,45] Add up the total number of points based on the patient's response.

16 or fewer points suggests a diagnosis other than COPD, possibly asthma. In this case, go to the adult asthma diagnosis guides (Tables 11 and 12)

17 or more points suggests a diagnosis of COPD. In this case go to Table 15

Table 15 COPD Diagnosis Guide $[7,8]$

\begin{tabular}{ll}
\hline & Findings that Support Diagnosis of COPD \\
\hline Physical examination & The following often occur in COPD but their absence should not be used \\
to rule out the disease: \\
- Expiratory wheeze on auscultation \\
- Increased expiratory time \\
- Hyperinflation \\
Response to treatment with bronchodilators, inhaled or oral steroids. \\
- FEV1/FVC $<0.70$ following bronchodilator administration. \\
(NOTE: PEF may underestimate airway obstruction; a normal PEF should \\
therefore not be used to exclude a diagnosis of COPD.) \\
- FEV1\% $<80 \%$ \\
Demonstration of irreversible airflow obstruction: This is defined as \\
Spirometry \\
below $12 \%$ FEV 1 reversibility and less than 200 ml change in FEV [7] $]^{* * * *}$, \\
or below $400 \mathrm{ml}$ change in FEV [8] according to the GOLD and NICE \\
guidelines respectively.
\end{tabular}




\section{Potential conflicts of interest}

Mark Levy has no shares in pharmaceutical companies. He has received speaker's honoraria for speaking at sponsored meetings from the following companies marketing respiratory products: IVAX, Astra Zeneca, BI, GSK, MSD and Schering-Plough. He has received honoraria for advisory panels with; Trinity Cheisi, 3M, Altana, Astra Zeneca, BI, GSK, MSD, Novartis, Schering-Plough. He has received funding for research projects from: $3 \mathrm{M}$, Astra Zeneca, GSK, Schering-Plough, Viatris. He has accepted sponsorship to attend conferences from: 3 M, Altana, Astra Zeneca, BI, GSK, MSD, Novartis, Schering-Plough, Viatris, Innovata Biomedica and Trinity Cheisi.

David Price has no shares in pharmaceutical companies. He has received speaker's honoraria for speaking at sponsored meetings from the following companies marketing respiratory products: $3 \mathrm{M}$, Altana, Astra Zeneca, BI, GSK, MSD, Novartis, Pfizer, Schering-Plough. He has received honoraria for advisory panels with; 3M, Altana, Astra Zeneca, BI, GSK, MSD, Novartis, Pfizer, Schering-Plough. He or his research team have received funding for research projects from: $3 \mathrm{M}$, Altana, Astra Zeneca, BI, GSK, MSD, Novartis, Pfizer, Schering-Plough, Viatris.

R Halbert is employed by Cerner Healun Insights, which provides consulting services top the pharmaceutical industry

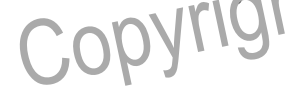

\section{Acknowledgements}

We thank Sarah DeWeerdt, freelance editor and writer, for her input into an early draft of this paper in which she helped us organize the information, determine the clearest format in which to present it, and in refining the wording of some recommendations.

We would also like to thank Professor $M$ Partridge, Dr R Spelman, and Dr E Dompeling who contributed to the early versions of this paper.

Thanks also to Mr L Grouse of MCR Vision Inc, for permission to use some of the tables published online in the IPAG Guideline [1].

Funding: During the development of these guidelines, the IPCRG received unrestricted educational grants from Altana, AstraZeneca, Boehringer Ingelheim, EAMG, GlaxoSmithKline, Merck Sharp and Dohme, Mitsubishi Pharma, Novartis, UCB Pharma, and Zambon. These funds were used for the purpose of funding face-to-face meetings and also to support a secretariat.

\section{References}

[1] International Primary Care Airways Group (IPAG). Chronic airways diseases: a guide for primary care physicians. Available at the URL http://www.ipagguide.org/IPAG_copyright_draft.pdf.

[2] Bellamy D, Bonchard J, Henrichsen S, Johansson E, Langhammer A, Reid J, van Weet C, Buist S. International Primary Care Respiratory Group (IPCRG) Guidelines: Management of Chronic Obstructive Pulmonary Disease (COPD). Prim Care Resp J 2006;15(1):48-57.

[3] van der Molen T, Ostrem A, Stallberg B, Stubbe Østergaard $M$, Singh RB. International Primary Care Respiratory Group (IPCRG) Guidelines: Management of asthma. Prim Care Resp J 2006;15(1):35-47.

[4] Price D, Bord C, Bonchard J, Costa R, Keenan J, Levy M, Orru M, Ryan D, Walker S, Watson M. International Primary Care Respiratory Group (IPCRG) Guidelines: Management of allergic rhinitis. Prim Care Resp J 2006;15(1):58-70.

[5] Royal College of General Practitioners. The development and implementation of clinical guidelines. Report of the clinical guidelines working group. London, 1995, RCGP.

[6] Dennis SM, Price J, Vickers MR, Frost C, Levy ML, Barnes $\mathrm{PJ}$. The management of newly identified asthma in primary care in England. Prim Care Respir J 2002;11(4):120-3.

[7] Global Initiative for Chronic Obstructive Lung Disease. Global Strategy for the Diagnosis, Management, and Prevention of Chronic Obstructive Pulmonary Disease. National Institutes of Health, National Hearc, Lung, and Blood Institute; April 2001 (Up data 2004), Available at URL: http:/ wwam.roldepd.com.

[8] National int tut for Clinical Excellence. Chronic bi) truclive pulmonary disease: management of adults with chronic bs ir t. e oulmonary disease in primary and soren dar. care Available at URL http://www.nice.org.uk/.

[S] C Is bal strategy for Asthma Management and Prevention. NiH Publication No 02-3659 Issued January, 1995 (updated 2002) Management Segment (Chapter 7): Updated 2005 from the 2004 document. The GINA reports are available at URL http://www.ginasthma.org.

[10] British guideline on the management of asthma, (2003) Thorax, 58 Suppl 1, Pages 1-94. BTS/SIGN. Available at URL http://www.sign.ac.uk/guidelines/fulltext/63/index.html.

[11] Pinnock H, Kaplan A, Ed Mark Levy. General Practitioners in Asthma Group. Spirometry Factsheet. (2004). Available at URL http://www.gpiag.org.

[12] van Schayck CP, Levy ML, Chen JC, Isonaka S, Halbert RJ. Coordinated diagnostic approach for adult obstructive lung disease in primary care. Prim Care Respir J 2004;13(4):218-21.

[13] Price D, Tinkelman D, Nordyke RJ, Isonaka S, Halbert RJ. Scoring system for symptom-based diagnostic questionnaires for COPD. Respirology 2004;9(Suppl 3):A97.

[14] Halbert RJ, Isonaka S. International Primary Care Respiratory Group (IPCRG) Guidelines: Integrating diagnostic guidelines for managing chronic respiratory diseases in primary care. Prim Care Resp J 2005;15(1): 13-9.

[15] Price D, Tinkelman DG, Halbert RJ, Nordyke RJ, Isonaka S, Nonikov D, Juniper EF, Freeman D, Hausen T, Levy ML, Østrem A, van der Molen T, van Schayck CP. Symptom-based questionnaire for identifying COPD in smokers. Respiration 2005; Published online ahead of print: doi:10.1159/000090142: http://content.karger. com/ProdukteDB/produkte.asp?doi=000090142 (accessed 15.12.2005). 
[16] Tinkelman DG, Price D, Halbert RJ, Nordyke RJ, Isonaka $S$, Nonikov D, Juniper EF, Freeman D, Hausen T, Levy ML, Østrem A, van der Molen T, van Schayck CP. Symptom-based questionnaire for differentiating COPD and asthma. Respiration. 2005; Published online ahead of print: doi:10.1159/000090141: http://content.karger. com/ProdukteDB/produkte. asp?doi=000090141 (accessed 15.12.2005).

[17] Bousquet, J, van Cauwenberge, P, Khaltaev, N, World Health Organization. Allergic rhinitis and its impact on asthma. In collaboration with the World Health Organization. Executive summary of the workshop report. 7-10 December 1999. Geneva, Switzerland. Allergy 57 [9], 841-855. 2002. See also Pocket Guide at URL http://www.whiar.com.

[18] Bousquet J. Allergic Rhinitis and its Impact on Asthma (ARIA) in collaboration with the World Health Organization (WHO). J Allergy Clin Immunol 2001;108:S147-336. See also Pocket Guide at URL http://www.whiar.com.

[19] Shrewsbury S, Pyke S, Britton M. Meta-analysis of increased dose of inhaled steroid or addition of salmeterol in symptomatic asthma (MIASMA). Br Med J 2000 May 20;320(7246):1368-73.

[20] Euler AR. Upper respiratory tract complications of gastroesophageal reflux in adult and pediatric-age patients. Dig Dis 1998;16:111-7.

[21] Halstead LA. Role of gastroesophageal reflux in pediatric upper airway disorders. Otolaryngol - Head Neck Surg 1999;120(208):14.

[22] Ruigomez A, Rodriguez LA, Wallander MA, Johansson S, Thomas M, Price D. Gastroesophageal Reflux Disease and Asthma: A Longitudinal Study in UK General Practice. Chest 2005;128:85-93.

[23] Kulig M, Bergmann R, Klettke U, et al. Natural courcs of sensitization to food and inhalant allergens during the first 6 years of life. J Allergy Clin Im nuns 17, : : :03 (0): 173-9.

[24] Thomas M, Kocevär $V$ ', 'Zhäng Y Yin DD, Pricet D.

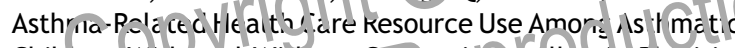
Chilcren Witir ard Witnout C ncomitant Allergic Rninitis. Paediatrics 2005;115(129):134

[25] Walker S. Self reported rhinitis is a significant problem for patients with asthma. Prim Care Respir J 2005;14(2):83-7.

[26] Burge PS. New guidelines for the management of occupational asthma in primary care and occupational health. Prim Care Respir J 2004;13:131-2.

[27] Cullinan P, Cullinan P. Clinical aspects of occupational asthma. Panminerva Medica 2004:111-20.

[28] Levy ML, Nicholson PJ. Occupational asthma case finding: A role for primary care. Br J Gen Pract 2004;54(507):731-3.

[29] Newman Taylor, AJ, Nicholson PJ. Guidelines for the prevention, identification and management of occupational asthma: Evidence review and recommendations.London: 2004. British Occupational Health Research Foundation. Also available at URL http://www.bohrf.org.uk/content/asthma.htm.

[30] ARIA. Allergic Rhinitis and its Impact on Asthma (ARIA). Management of Allergic Rhinitis Symptoms in the Pharmacy:
ARIA in the Pharmacy. Allergy 2004;59:373-87. Also available at the URL http://www.whiar.org.

[31] Anbar, RD, Lannuzzi, DM. The wheezing child. SUNY Upstate Medical University, Department of Pediatrics Pulmonary Disease Manual. 2005. Also available at URL www.ec.hscsyr.edu/peds/pulmonary_manual.html.

[32] Frank PI, Frank TL, Cropper J, et al. The use of a screening questionnaire to identity children with likely asthma. $\mathrm{Br} \mathrm{J}$ Gen Prac 2001;51(463):117-20.

[33] Shaw RA, Crane J, O'Donnell TV, Lewis ME, Stewart B, Beasley R. The use of a videotaped questionnaire for studying asthma prevalence. a pilot study among new zealand adolescents. Med J Aust 1992;157(5):311-4.

[34] Wolf RL, Berry CA, O’Connor T, Coover L. Validation of the Brief Pediatric Asthma Screen. Chest 1999;116(4 Suppl. 1).

[35] Frank TL, Frank PI, Hirsch S, et al. Assessment of a simple scoring system applied to a screening questionnaire for asthma in children aged 5-15 yrs. Eur Respir J 1999;14(5):1190-7.

[36] Jenkins MA, Hopper JL, Choi K, et al. Validation of questionnaire and bronchial hyperresponsiveness against respiratory physician assessment in the diagnosis of asthma. Intl J Epidemiol 1996;25(3):609-16.

[37] Shaw RA, Crane J, Pearce N, et al. Comparison of a video questionnaire* with the IUATLD written questionnaire for measuring asthma prevalence. Clin Exp Allergy 1992;22(5):561-8.

[38] Sistek D, Tschopp J, Schindler C, et al. Clinical Diagnosis of Current Asthma: Predictive Value of Respiratory Symptoms in the SAPALDIA Study. Eur RerpIr '200 ; ; $;(2): 214-9$.

[39] Ravault C, Kauffmann /SVaidi y of the IUATLD (1986) Questioninaire in re EGEA Study. Intl J Tuberculosis Lung Dis 2) $01 ; 5(2): 191-6$.

[4C] Tschopp .M. 'Siste' D, Schindler C, et al. Current Allergic A: hina and Kininitis: Diagnostic Efficiency of Three Cprarioniy used Atopic Markers (IgE, Skin Prick Tests, and Phadiatop ${ }^{\circledR}$ ): Results from 8329 Randomized Adults from the SAPALDIA Study. Allergy: Eur J Allergy Clin Immunol 1998;53(6):608-13.

[41] Abramson MJ, Hensley MJ, Saunders NA, Wlodarczyk JH. Evaluation of a New Asthma Questionnaire. J Asthma 1991;28(2):129-39.

[42] Burney PGJ, Laitinen LA, Perdrizet S, et al. Validity and Repeatability of the IUATLD (1984) Bronchial Symptoms Questionnaire: An International Comparison. Eur Respir J 1989;2(10):940-5.

[43] Health and safety Executive UK. Occupational asthma and work related asthma. Available at URL http://www.hse.gov.uk/asthma/causes.htm\#occupational.

[44] Tinkelman D, Price D, Nordyke RJ, Isonaka S, Halbert RJ. Questionnaire for differential diagnosis of obstructive lung disease. Eur Respir J 2004;24(Suppl 48):473s.

[45] Price D, Tinkelman D, Nordyke RJ, Isonaka S, Halbert RJ. Scoring system for symptom-based diagnostic questionnaires for COPD. Respirology 2004;9(Suppl 3): A97.

Available online at www.sciencedirect.com science@Direct. 